\title{
1. Improving international uniform transport law by creating interpretative committees ${ }^{1}$ \\ Cécile Legros ${ }^{2}$
}

\section{INTRODUCTION}

The term "uniform law" refers to all international legal instruments designed to apply identically in different States. ${ }^{3}$ Among these various instruments, international private law conventions create rules uniformly applicable in the contracting States in order to avoid the disparate treatment caused by domestic legislation applied through a conflicts-of-laws mechanism. One of the advantages of such a system is that by increasing legal certainty, it encourages the development of international trade.

Adopting a set of uniform rules proves ineffective, however, if the courts hearing cases in the different countries that are party to these conventions do not apply these rules uniformly. ${ }^{4}$ And yet, we can all cite several examples of divergent applications of international conventions. The field of transport is not immune to these discrepancies and there are many examples of divergent interpretations of international transport conventions, some of which are likely to undermine the convention's goal of uniformity. ${ }^{5}$

The benefits of uniform interpretation are the same as those of uniform law: applying the same rule all over the world when more than one legal system is involved leads to such legal certainty that the benefits do not even seem to be discussed anymore. ${ }^{6}$ As regards the purpose of international private law conventions (that is, to apply the same rule in different countries), divergent interpretations or applications of a convention can

1 This chapter was presented during the INTRANSLAW Conference, Zagreb 2017, under the following title: "Can Interpretative Committees be created to Improve Uniform Interpretation of international transport conventions?" <http://intranslaw.hdtp.eu/> accessed 4 March 2019.

2 Pr. Cécile Legros, Ph. D., Normandie Univ, UNIROUEN, CUREJ, 76000 Rouen, France.

3 Mario Mattecci, 'Introduction à l'étude systématique du droit uniforme', (1957) I Recueil des Cours de l'Académie internationale de La Haye 387.

4 Stefania Bariatti, 'L'interpretazione delle convenzioni internazionali di diritto uniforme' (1986) XVI Rivista di diritio internazionale privato e procesuale 339. Franco Ferrari, 'Uniform Interpretation of the 1980 Uniform Sales Law' (1994) 24 Ga. J. Int'l \& Comp. L. 183 <http://digitalcommons.law.uga.edu/gjicl/vol24/iss2/2> accessed 4 March 2019.

5 Richard K Gardiner, Treaty Interpretation (2nd edn, Oxford University Press 2017) ch 1; see also, Antonio Malintoppi, 'The Uniformity of Interpretation of International Conventions on Uniform Laws and of Standard Contracts' in Clive M Shmitthoff (ed), The Sources of the Law of International Trade with Special Reference to East-West Trade (Persée 1965) 17(4) Revue internationale de droit comparé $1020<$ https://www.persee.fr/doc/ridc_0035-3337_1965_num_ 17_4_14455> accessed 11 May 2018.

6 Michael E Sturley, 'International Uniform Laws in National Courts: The Influence of Domestic Law in Conflicts of Interpretation' (1986) Virginia Journal of International Law 729, 731. 
be regarded as deviations from that convention's main purpose, and even an infringement of it. While some differences may be minor and thus acceptable, others may be contrary to the convention's objective.

The main causes of divergent interpretations will briefly be discussed below. But the specific purpose of this chapter is to explore remedies that could help make interpretation more uniform. ${ }^{7}$ After discussing traditional remedies, I will pay special attention to the possible development of interpretation bodies. First, however, I will illustrate the issue at hand with a few examples of divergent interpretations.

One of the most well-known sources of such interpretations in the field of international carriage of goods by road is provided by Article 29(1) of the Convention on the Contract for the International Carriage of Goods by Road (CMR), ${ }^{8}$ which specifies that:

The carrier shall not be entitled to avail himself of the provisions of this chapter which exclude or limit his liability or which shift the burden of proof if the damage was caused by his wilful misconduct or by such default on his part as, in accordance with the law of the court or tribunal seized of the case, is considered as equivalent to wilful misconduct. (Emphasis added)

Whether such article leads to diverging interpretations or not is a controversial issue. As the provision itself turns to national law, the national courts should not be considered as infringing the convention when they apply such national law. However, the italicized terms have been subject to several different interpretations. Some of them deny that the objective of the authors of the convention was to refer to domestic law to qualify wilful misconduct. ${ }^{9}$

The provision sets out a conventional limitation of the carrier's liability, provided the damage was not caused by its wilful misconduct, or the equivalent according to the law of the seized court. Most domestic courts interpreted this wording as a requirement to refer to the domestic law to appreciate the gravity of the fault committed by the carrier. It thus led to totally inconsistent results in different State Parties to the convention. The same act ${ }^{10}$ might therefore be characterized as faute inexcusable equivalent to dolus in France, ${ }^{11}$ but not be considered wilful misconduct by English courts. ${ }^{12}$ This is not

7 Jacques Putzeys, 'Les tendances unificatrice et désunificatrices dans le droit des transports de marchandises: perspectives' (2003) 1 Uniform Law Review 233.

8 Convention on the Contract for the International Carriage of Goods by Road (CMR) (Geneva, 19 May 1956) <www.jus.uio.no/lm/un.cmr.road.carriage.contract.convention.1956/doc. html\#1> accessed 4 March 2019.

9 E Krings, 'La Cour de cassation et l'interprétation de la CMR' in Liber amicorum Jacques Putzeys (Bruylant 1996) 133; see also, René Loewe, 'Note explicative sur la Convention relative au contrat de transport international de marchandises par route (CMR) du 19 mai 1956' (1975) Nations Unies, Geneva ECE/TRANS/14, 17-18, para 50.

10 For instance: the fact of parking in an unsecured parking lot, leading to theft of the transported goods.

11 Before the Act of 8 December 2009, considering that the only fault "equivalent to dolus" is now the faute inexcusable (art L 133-8 Commercial Code).

12 Jean Lecaroz and Nicolas Michon, 'L'article 29 de la CMR en pratique' (2016) 21, 4 Uniform Law Review 549 <https://doi.org/10.1093/ulr/unw031> accessed 4 January 2018. 


\section{Research handbook on maritime law and regulation}

merely a minor discrepancy in the application of the convention since, in the first case, the carrier will have to compensate the damage fully, but will benefit from the conventional limit on compensation in the second.

Such doubts about how to interpret the concept of "wilful misconduct" also arise with respect to maritime and air-transport law.

Many examples of divergent interpretations in maritime case law involve the Hague-Visby Rules. ${ }^{13}$ The English courts and arbitration tribunals under English organizations are known for their pro-carrier interpretation, as compared to the more balanced interpretation in other countries. ${ }^{14}$ Other sources of frequent interpretational differences are the special bill of lading provisions, such as "said to be" and FIO/FIOS clauses, ${ }^{15}$ as well as the applicability of the Hague-Visby Rules to on-deck carriage, ${ }^{16}$ and the applicability of the nautical fault exemption. ${ }^{17}$

One of the many examples in the area of air transport relates to Article 18 of the Warsaw convention, ${ }^{18}$ the scope of which is rather unclear because interpretations differ as to the moment when the goods are "in the charge of the carrier". ${ }^{19}$

1. The carrier is liable for damage sustained in the event of the destruction or loss of, or of damage to, any registered luggage or any goods, if the occurrence which caused the damage so sustained took place during the carriage by air.

2. The carriage by air within the meaning of the preceding paragraph comprises the period during which the luggage or goods are in charge of the carrier, whether in an aerodrome or on board an aircraft, or, in the case of a landing outside an aerodrome, in any place whatsoever.

3. The period of the carriage by air does not extend to any carriage by land, by sea or by river performed outside an aerodrome. If, however, such a carriage takes place in the performance of a contract for carriage by air, for the purpose of loading, delivery or transshipment, any damage is presumed, subject to proof to the contrary, to have been the result of an event which took place during the carriage by air.

13 International Convention for the Unification of Certain Rules of Law relating to Bills of Lading (1924)/First Protocol (1968)/Second Protocol (1979) (Drafted 25 August 1924/23 February 1968/21 December 1979 - Effective 2 June 1931/23 June 1977/24 February 1982) <www.jus.uio.no/lm/sea.carriage.hague.visby.rules.1968/doc.html> accessed 4 March 2019.

14 Francisco Berlingeri, 'Unification and Harmonisation of Maritime Law Revisited' (2007) Diritto marittimo, 28. Georges Marais, Les transports internationaux de marchandises par mer et la jurisprudence en droit comparé (LGDJ 1949) 18.

15 Martin Davies, 'Two Views of Free In and Out, Stowed Clauses in Bills of Lading' (1994) 22, 3 Australian Business Law Review 198.

16 Ralph Ashton, 'A Comparison of the Legal Regulation of Carriage of Goods by Sea under Bills of Lading in Australia and Germany' (1999) 14 MLAANZ Journal 24, 48.

17 Mads Schjølberg, 'Interpreting Uniform Law, the Norwegian Perspective' (Master Thesis, University of Oslo, unpublished 2016) 42 <https://www.duo.uio.no/handle/10852/51496> accessed 3 January 2018.

18 Convention for the Unification of certain rules relating to international carriage by air (adopted 12 October 1929, entered into force 13 February 1933).

19 Paul Myburgh and Geoff Mercer, Practical Aspects of the Law Relating to Carriage of Goods (15 March 1995) <https://ssrn.com/abstract=2578762> or <http://dx.doi.org/10.2139/ ssrn.2578762> accessed 3 January 2018. 
Unfortunately such examples abound. To explore possible remedies, it is first necessary to review the main causes of such discrepancies.

\section{CAUSES OF DIVERGENT INTERPRETATIONS 20}

Several explanations can be identified. The different methods for making international conventions enforceable in State Parties may explain the phenomenon, but the main issue is the lack of an international court.

\section{A. Monist and Dualist Legal Systems}

Some interpretation discrepancies may result from the different ways international conventions are rendered enforceable in the monist and dualist legal systems. Uniform multilateral conventions become enforceable in State Parties either by enactment as a domestic law, or by ratification of the convention. But even in countries where conventions are self-executing, uniform laws sometimes constitute "model laws" that must also be enacted as domestic law. ${ }^{21}$

Unlike the dualist system, the monist legal system does not require international conventions to be incorporated into national law by means of an additional act of parliament, such as a new law. The international convention can be directly invoked and applied before domestic courts. ${ }^{22}$ France belongs to this system, as do many civil law countries. This is also the case for the United States.

In dualist countries however, international conventions are implemented via the adoption of a domestic law that incorporates the convention. ${ }^{23}$ Sometimes the content of the domestic law differs from the content of the convention. In addition, such a system is more likely to encourage domestic interpretations of the text rather than international uniform interpretation, as the court may not recall the international origin of the law: the text applied by the court is in fact domestic legislation and it is therefore understandable that judges are likely to construe it according to national concepts and case law. ${ }^{24}$ The same phenomenon can be observed even in monist countries when an

20 Michael E Sturley, 'International Uniform Laws in National Courts: The Influence of Domestic Law in Conflicts of Interpretation' (1986) Virginia Journal of International Law 729, 731.

21 Example: UNCITRAL Model Law on International Commercial Arbitration 1985 with

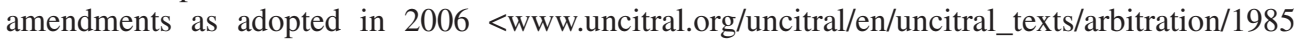
Model_arbitration.html> accessed 11 June 2018.

22 Example of a French case involving The Hague-Visby Rules: Cass Com, 18 November 2014, no. Z 13-23879, DMF 2015.765, Rapp. J Lecaroz, discussed by Cécile Legros 'Conditions de l'éviction de la convention de Bruxelles en cas de chargement en pontée (Obs. sous Cass. Com., 18 novembre 2014, nZ 13-23879, inédit)' (2015) 41, 1475 JCP, ed E\&A, no 8.

23 On "hybrid regimes" see Paul Myburgh, "Uniformity or Unilateralism in the Law of Carriage of Goods by Sea?' (2000) 31(2) Victoria University of Wellington Law Review 355 <www5.austlii.edu.au/nz/journals/VUWLawRw/2000/22.htm> accessed 3 January 2018.

24 Gardiner (n 4); see also Angelos Yokaris, 'L'application du droit conventionnel international en droit interne - Analyse comparative de l'application effective de la Convention de 


\section{Research handbook on maritime law and regulation}

international instrument is codified, ${ }^{25}$ even when such codification does not modify the convention's content in any way.

In this context, it seems unfortunate that all the efforts necessary to successfully negotiate an international instrument can be undermined by divergent applications by domestic courts. ${ }^{26}$

Regardless of the system, domestic courts are able to interpret international conventions as if they were interpreting domestic law because there is no unique international court competent to rule on these international instruments, and therefore no uniform, international interpretations to follow. This fosters discrepancies because all decisions related to such instruments are rendered by national courts, which have different legal cultures.

\section{B. Lack of an International Court}

Arguably, the main reason for diverging interpretations of international treaties is the lack of an international tribunal empowered to render binding decisions. ${ }^{27}$ This is not entirely true, as the universal jurisdiction of the International Court of Justice (ICJ) should mean this court can solve these problems. As I will show, however, even if in theory the ICJ could uniformly interpret international conventions, in practice this remedy does not appear to be efficient.

As a global court the ICJ has two types of jurisdiction. Firstly, as a court it resolves legal disputes submitted to it by States, in accordance with international law. Secondly, as an advisory body, it gives advisory opinions on legal questions at the request of the organs of the United Nations (UN) or specialized agencies authorized to make such requests. Only States have standing to appear before the Court with respect to a dispute. Public (governmental) international organizations cannot as such be parties to a case. However, the advisory procedure is available to such organizations. Such procedure is laid down in Article 96.1 of the Charter of the United Nations: "The General Assembly or the Security Council may request the International Court of Justice to give an advisory opinion on any legal question." Article 96.2 then provides that "other organs of the United Nations and specialized agencies, which may at any

Varsovie' (1980) RFDA 146, 149; Paul Chauveau, 'Les responsabilités des transporteurs' in Le droit privé français au milieu du vingtième siècle: études offertes à Georges Ripert (t. 2, LGDJ 1950) 398, 409.

25 This situation frequently arises when the international convention also covers domestic situations: for example German road transport law implementing the CMR.

26 Discussed by Viscount Simonds before the British House of Lords in Scruttons Ltd v Midland Silicones Ltd, [1962] AC 446, 471.

27 Otto Riese Otto, 'Une juridiction supranationale pour l'interprétation du droit unifié' (1961) 13 Revue internationale de droit comparé $717<$ https://www.persee.fr/doc/ridc_00353337_1961_num_13_4_13266> accessed 12 June 2018. See also Philippe Duboc, 'Le respect des conventions internationales par les juridictions françaises' (PhD Thesis, Rouen Normandie University 2009). Contra Matteucci Mario, 'L'évolution en matière d'unification du. droit' (1961) 13 Revue internationale de droit comparé 285 <https://doi.org/10.3406/ridc.1961.13066> accessed 3 July 2018. 
time be so authorized by the General Assembly, may also request advisory opinions of the Court on legal questions arising within the scope of their activities".

In practice, there is no example of a State Party to the UN Charter submitting a dispute related to an international trade convention, such as a transportation convention, to the ICJ. Even though the CMR specifically provides for interpretation by that court (Article 47), it has never been invoked before the ICJ, and doing so seems rather inefficient. ${ }^{28}$

On the contrary, several specialized agencies operating in the field of transport have used the advisory procedure. The International Maritime Organization (IMO) asked the ICJ for an advisory opinion in a case regarding the establishment of the Maritime Safety Committee of the Inter-Governmental Maritime Consultative Organization, which led to an ICJ opinion issued in 1960.29 The International Civil Aviation Organization (ICAO) is also one of the organizations entitled to ask the Court for advisory opinions, but it has not made use of this possibility.

The case concerning the International Maritime Organization ${ }^{30}$ concerned an issue related to the composition of the Maritime Safety Committee. The former organization (IMCO) comprised, among other organs, an Assembly and a Maritime Safety Committee. This committee was composed of 14 of the organization's members. These members, which were elected by the Assembly, had to have an important interest in maritime safety, and at least eight of them had to "be the largest ship-owning nations". ${ }^{31}$ The committee was elected in 1959 and neither Liberia nor Panama was elected, although those two States were among the eight members of the organization that possessed the largest registered tonnage. Subsequently, the Assembly decided to petition the ICJ to ask it whether the Maritime Safety Committee had been constituted in accordance with the rules of the Convention establishing the IMCO organization. In its Advisory Opinion of 8 June 1960, the Court replied to this question in the negative.

Given the general wording of the UN Charter, it seems possible to refer issues to the Court that relate to the interpretation of uniform-law conventions. Such opinions would obviously be very useful: even though the Court's advisory opinions have no binding effect, they nevertheless carry great legal weight and moral authority, and as such could help improve international uniform law.

As both these transport organizations (IMO and ICAO) are entitled to ask the ICJ for advisory opinions, one might wonder why this procedure has not been used more often. In my opinion, the reason is the overall timing and cumbersomeness of the referral process. Because only certain international organizations (not private trade operators/ stakeholders) can petition the Court, issues first must be discussed before the competent organs of such organizations, and only when consensus has been achieved within the organization can the issues be referred to the ICJ, which will probably take

28 Cécile Legros, 'Modalités de l'interprétation uniforme de la CMR: Quelles difficultés? Quels remèdes?’ (2016) 21 Uniform Law Review 427 <https://doi.org/10.1093/ulr/unw032> accessed 3 January 2018.

$29<w w w . i c j-c i j . o r g / e n / c a s e / 43>$ accessed 3 January 2018.

30 At the time of the case the organization was the Inter-Governmental Maritime Consultative Organization (IMCO); it has now been replaced by the International Maritime Organization (IMO).

31 Art 28 (a) of the Convention for the establishment of the IMCO. 
a few years to issue an opinion. Without denying the great benefit of such authoritative opinions, I believe that this procedure, which is mainly designed for diplomatic purposes, is not relevant for legal issues related to international trade. As non-binding opinions can be rendered by international organizations, the international transport organizations could simply skip the ICJ step and issue their own opinions. ${ }^{32}$

The lack of international uniform interpretation methods is another explanation for the failure to achieve uniform interpretation.

\section{Lack of Uniform Interpretation Methods}

On the international level, Article 31 of the Vienna Convention on the Law of Treaties theoretically provides a uniform method of interpretation. ${ }^{33}$ Though this treaty applies in more than half the world's countries, ${ }^{34}$ it does not seem to be used very widely by domestic courts, where national legal culture predominates. Broadly speaking, common law judges tend to seek authoritative guidance from prior judicial or arbitral decisions, whereas civil law judges are inclined to rely far more on academic commentaries and travaux préparatoires. ${ }^{35}$

According to Claude Witz's work on the first judicial applications of the International Convention on Sales of Goods (CISG - 1980), ${ }^{36}$ it appears that European legal tradition tends to value academic commentaries as a source of law. But Witz also strongly believes it is useful to disseminate case law to instruct judges and arbitrators. He suggests that uniformity could be improved through a "hybrid methodology" of encouraging civil law judges to increase their reliance on precedents as a source of binding authority, while judges in common law jurisdictions should more frequently seek elucidation of relevant legal principles in scholarly writings.

An example of the use of such a "hybrid methodology" is the remarkable opinion of Lord Wilberforce in the Buchanan case. ${ }^{37}$ This case concerned the interpretation of Article 23(4) of the CMR convention, which is written in both English and French,

32 See n $2813 \mathrm{ff}$.

33 The Vienna Convention on the Law of Treaties was adopted 23 May 1969 and entered into force 27 January 1980. It has been ratified by 114 states as of April 2014. Some countries, such as France and the United States, have not ratified the Convention but recognize parts of it as a restatement of customary law and binding on them as such. See Gardiner (n 4). See also Malgosia Fitzmaurice, 'Treaty Interpretation' [2009] 20(3) European Journal of International Law 952 <https://doi.org/10.1093/ejil/chp045> accessed 3 January 2018; Waldemar Czapski, 'Interprétation de la Convention CMR à la lumière du droit international public' (2006) 3 Intl L. Rev. 145.

34116 States are currently party to this convention.

35 Kent Greenawalt, Statutory and Common Law Interpretation (Oxford University Press 2013); Gardiner (n 4) 51ff. See also Richard K Gardiner, 'Interpreting Treaties in the United Kingdom' in M Freeman (ed), Legislation and the Courts (Dartmouth Publishing 1997), 115.

36 Claude Witz, Les premières applications jurisprudentielles du droit uniforme de la vente internationale (LGDJ 1995).

37 James Buchanan and Co Ltd v Babco Forwarding and Shipping Ltd [1977] QB 208; [1978] AC 141, 152, per Lord Wilberforce; [1978] 1 Ll L Rep - UNILAW Registration Number: CMR UK 22; RJC Munday, 'The Uniform Interpretation of International Conventions' (1978) 27(2) The International and Comparative Law Quarterly 450, 451. 
with each text being equally authentic. After noting that different principles of interpretation could be applied, Lord Wilberforce strongly advocated for an international approach to interpreting such conventions:

The English text alone appears in the schedule to the 1965 Act, and is by that Act (s. 1) given the force of law. Moreover the contract of carriage seems to have incorporated contractually this English text. It might therefore be arguable (though this was not in fact argued) by distinction from a case where the authentic text is (e.g.) French and the enacted text an English translation that only the English text ought to be looked at. In my opinion this would be too narrow a view to take, given the expressed objective of the Convention to produce uniformity in all contracting states. I think that the correct approach is to interpret the English text which after all is likely to be used by many others than British business men, in a normal manner, appropriate for the interpretation of an international convention, unconstrained by technical rules of English law, or by English legal precedent but on broad principles of general acceptation. ${ }^{38}$ Moreover, it is perfectly legitimate in my opinion to look for assistance, if assistance is needed, to the French text. This is often put in the form that resort may be had to the foreign text if (and only if) the English text is ambiguous, but I think this states the rule too technically. As Lord Diplock recently said in this House the inherent flexibility of the English (and, one may add, any) language may make it necessary for the interpreter to have recourse to a variety of aids. ${ }^{39}$ There is no need to impose a preliminary test of ambiguity. ${ }^{40}$

Despite such a brilliant plea, domestic courts still tend to resort to national interpretation methods. Their lack of international reflexes could be mitigated by the inclusion of dedicated provisions in every international convention. ${ }^{41}$ Unfortunately most conventions, even the more recent ones, do not include such provisions. ${ }^{42}$ However, Article 2 - Interpretation of this Convention - of the Rotterdam Rules ${ }^{43}$ provides that "[i]n the interpretation of this Convention, regard is to be had to its international character and to the need to promote uniformity in its application and the observance of good faith in international trade". Even if such a provision does not provide sufficient guidance to the courts that will eventually apply the convention, it is to be welcomed and should be inserted into every uniform convention. ${ }^{44}$ Until that happens, interpretation of these instruments remains within the jurisdiction of domestic courts, which are likely to interpret them according to domestic rules.

38 Stag Line Ltd v Foscolo Mango and Co Ltd [1931] 41 Ll L Rep 165; [1932] AC 328.

39 Carter v Bradbeer [1975] 3 All ER 158, 161.

40 Buchanan (n 36).

41 See Parts II and III of this chapter.

42 United Nations Convention on Contracts for the International Carriage of Goods Wholly or Partly by Sea (New York 2008) (adopted by the General Assembly on 11 December 2008 not in force) <www.uncitral.org/pdf/english/texts/transport/rotterdam_rules/Rotterdam-RulesE.pdf> accessed 4 March 2019.

43 Very similar to art 3 of the Hamburg Rules: United Nations Convention on the Carriage of Goods by Sea (Hamburg 1978) (adopted 31 March 1978, entered into force 1 November 1992) <www.uncitral.org/pdf/english/texts/transport/hamburg/hamburg_rules_e.pdf> accessed 4 March 2019.

44 For a few examples, see Witz (n 35), 54. 


\section{Research handbook on maritime law and regulation}

Apart from encouraging local courts to use the Vienna Convention as a common international reference, the acknowledgment of international case law is also necessary to enable the emergence of a uniform body of case law.

\section{Failure to Disseminate Foreign Case Law}

One of the reasons domestic courts rarely refer to foreign decisions is undoubtedly the non-binding nature of such sources, but they are also unaware of them. And even if foreign case law is not binding, it can become an inspiration. ${ }^{45}$ To achieve such a goal, these decisions have to be ranked and disseminated, but there is no official website, and specialized reliable databases are rare. ${ }^{46}$

Even when a convention encourages such a compilation, the resolutions are not always followed by action. The final resolution of the Hague diplomatic conference in 1964 for the adoption of the Uniform Law on International Sales (ULIS) and the Uniform Law on the Formation of Contracts (ULFC) can be mentioned as an example: "Each Contracting State shall use its best endeavours to assist the International Institute for the Unification of private law in compiling each year a list of the judicial and arbitral decisions of major importance relating to the interpretation and application of the Uniform Law on the International Sale of Goods ..."47 Of course this example is not really relevant, as both laws have been superseded by the CISG. ${ }^{48}$ But it shows that even when the authors of a convention provide for specific recommendations on the need to collect major case law, these recommendations go unheeded.

Even the works on the CISG, which developed the most efficient system for disseminating case law, highlight shortcomings. The study of case law shows the failure to develop general principles through autonomous interpretation. According to JE Murray, "These failures may be due to a lack of familiarity with the Convention, but

45 A rare example of the Norwegian Supreme Court relying on foreign case law in interpreting a uniform law provision may be found in Sunny Lady (ND 1975.85), a case regarding the nautical fault exemption. The cargo side argued, inter alia, that the nautical fault exemption was of no avail to the ship owner due to initial unseaworthiness. The Norwegian Supreme Court rejected the argument of initial unseaworthiness. When setting out the general standard of seaworthiness in its assessment of the cargo side's argument, the court referred to the judgment of the US Supreme Court in Racer (Mitchell v Trawler Racer, 362 US 539), which stated that the "standard is not perfection, but reasonable fitness". Whilst a clear example of a court using foreign case law to interpret domestic provisions enacting uniform laws, the reference is brief and never expressed as an interpretive approach driven by deference to international uniformity.

46 The only successful experiment is the UNCITRAL CLOUT <www.uncitral.org/clout/> accessed 4 March 2019.

47 Records and Documents of the Diplomatic Conference on the Unification of Law Governing the International Sale of Goods (The Hague, 2-25 April 1964), 2 vol., ed by the Ministry of Justice of the Netherlands, the Hague, 1966, p. 330.

48 And the UNILAW database has never been a success. 
they may also be due to an unconscious adherence to the domestic traditions of these courts." 49

In the field of transport conventions, the experience of the French International Transport Law Institute (IDIT) must also be mentioned. This Institute runs the CMR UNIDROIT-IDIT database, ${ }^{50}$ which was developed by the International Institute for the Unification of Private Law (UNIDROIT) and transferred to the IDIT in 2012. This freely accessible database contains about 3000 French and foreign decisions related to the CMR. But it must be recognized that the base is not yet sufficiently well known, and therefore not sufficiently consulted, to be considered an effective instrument for improving uniform application of the CMR.

To encourage domestic courts to take foreign case law into account, 51 formal consultation procedures should be developed by national judicial organs. In most countries, when courts (especially lower courts) are seized with a case involving an international convention, there is no procedure to guide them. In France, the documentation department of the Cour de cassation can provide material on foreign case law for the judges. But there is no real formalized, efficient system. The London convention (European Convention of 7 June 1968 on Information on Foreign Law) ${ }^{52}$ was drafted specifically for this purpose but has never worked well.

To overcome these issues, remedies must be found. At present, traditional remedies prove rather ineffective. That is why the creation of interpretation bodies will be further explored.

\section{TRADITIONAL REMEDIES TO IMPROVE UNIFORM INTERPRETATION}

Several ordinary and more innovative remedies have already been proposed, the main one being to create an international interpretative court. This would certainly be the best remedy, but it somehow seems quite utopic at present. Works on terminology have also proven to be effective to some degree in reducing interpretation discrepancies. Developing international interpretation guidance could also help to avoid domestic approaches.

\section{A. International Interpretative Court}

Among the traditional remedies, the need to create an international court competent to hear disputes arising from international commercial conventions is frequently invoked.

49 John E Murray, Jr, 'The Neglect of CISG: A Workable Solution' (1998) Journal of Law and Commerce $365<$ https://www.cisg.law.pace.edu/cisg/biblio/murray1.html\#d34> accessed 3 January 2018.

$50<$ <ww.idit.asso.fr> accessed 4 March 2019.

51 Marie-Caroline Pitton, Le Rôle du Jugement étranger dans l'interprétation du droit conventionnel uniforme (Eleven International Publishing 2013).

52 European Convention on Information on Foreign Law (adopted 7 June 1968, entered into force 17 December 1969) ETS No.062. 


\section{Research handbook on maritime law and regulation}

Of course the ICJ could, and even should, be this court. But it must be noted that it does not function in a way that can provide the efficiency required by international trade. And even if some academics and lawyers advocate resort to the advisory mechanism of the ICJ, ${ }^{53} \mathrm{I}$ do not think this mechanism could provide an adequate solution as far as international trade law is concerned.

Some regional courts, such as the European Union Court of Justice (ECJ), could provide a solution. As the European Union (EU) is now an autonomous party to these conventions, or as some of them have been integrated into EU regulations, ${ }^{54}$ the ECJ is entitled to interpret some international instruments, especially when the convention has been enacted in EU law through a regulation. ${ }^{55}$ In such cases, an ambiguous term of the regulation may be interpreted by the ECJ. As such term is likely to be the same in the "parent" convention, such interpretation could be reused by domestic courts when interpreting the convention. One of the most relevant cases decided by the European Court of Justice is the Walz case. ${ }^{56}$ This case concerned the interpretation of Council Regulation (EC) No 2027/97 of 9 October 1997 on air carrier liability in respect of the carriage of passengers and their baggage by air, which specifically refers to the Montreal convention. ${ }^{57}$ Article 1 of the 1997 Regulation, ${ }^{58}$ as amended by Regulation (EC) No 889/2002 of the European Parliament and of the Council of 13 May 2002,59 provides: "This Regulation implements the relevant provisions of the Montreal Convention in respect of the carriage of passengers and their baggage by air and lays down certain supplementary provisions ..." The preliminary ruling concerned the interpretation of Article 22, paragraph 2 of the Montreal convention on the notion of prejudice and damage, neither of which were defined in the convention. Conscious that it was interpreting an international instrument, the ECJ took many precautions and stressed the need to interpret such notions according to international law. That decision was therefore likely to be taken into consideration by State Parties to the Montreal convention outside the European Union.

However, while such decisions may have more persuasive value than those issued by domestic courts, they are not binding on courts outside the EU. In addition, the ECJ is

53 See above pp. 6-7.

54 Cécile Legros, 'L'intégration des conventions internationales dans le droit dérivé: l'exemple du droit des transports' in Mélanges à la mémoire de Patrick Courbe (Dalloz 2012) 367.

55 Two major regulations illustrate this phenomenon: Regulation (EC) No 392/2009 of the European Parliament and of the Council of 23 April 2009 on the liability of carriers of passengers by sea in the event of accidents, partially integrating the Athens Convention relating to the Carriage of Passengers and their Luggage by Sea, 1974 and the Council Regulation (EC) No 2027/97 of 9 October 1997 on air carrier liability in the event of accidents, OJ L 285, 17/10/1997 P 0001-0003.

56 C-63/09, Walz v ClickAir SA [2010], ECR I-4239. See Jean-Pierre Tosi, 'La Convention de Montréal sur la responsabilité du transporteur aérien relève de la compétence interprétative de la CJUE' [2010] Recueil Dalloz 1762.

57 Convention for the Unification of Certain Rules for International Carriage by Air (signed 28 May 1999 in Montreal, Canada; entered into force 4 November 2003).

58 OJ 1997 L 285, p. 1.

59 OJ 2002 L 140, p. 2, 'Regulation No 2027/97'. 
not entitled to interpret international conventions that are not part of EU law, even when most of a convention's State Parties are EU members. ${ }^{60}$

Thus, resorting to regional courts brings only partial solutions.

There is at least one genuine mechanism in the field of transport law:61 the procedure set up by the Intergovernmental Organization for International Carriage by Rail (OTIF) to interpret the Convention concerning International Carriage by Rail (COTIF) of 1999. OTIF is dedicated to international rail transport, and more specifically to developing unified railway law to connect Europe, Asia and Africa. This organization has created a special body to interpret the Convention, which is likely to enhance uniform interpretation.

The organization relies on the COTIF, which comprises two parts: the Convention itself, which governs the running of the Organization, as well as its objectives, attributions, relations with the Member States and its activities in general; and the seven Appendices establishing uniform railway law. ${ }^{62}$

The statutory part of the Convention refers several times to interpretation issues. First, Article 8(1) insists on the need to take into account the Convention's character of international law and the necessity to promote uniformity when interpreting and applying the Convention. Second, Article 21, which defines the functions of the Secretary General, states in paragraph 3(j) that such officer may "endeavour, at the request of one of the parties concerned, by using his [sic] good offices, to settle disputes between them arising from the interpretation or application of the Convention". Such provision can be interpreted as giving the Secretary General authority to conduct voluntary mediation before a dispute leads to litigation.

But the most interesting provisions can be found under Title $\mathrm{V}$, dedicated to arbitration. Article 28(1) gives competence for all disputes between Member States arising from the interpretation or application of the Convention to a special internal

60 C-533/08, TNT Express Nederland BV v AXA Versicherung AG [2010] OJ C79/7: in this case the ECJ refuses to interpret the CMR, being an international and not a European instrument.

61 The Chamber of Appeal of the Central Commission for the Navigation of the Rhine which provides for an optional uniform court of appeal in inland water cases may also be mentioned: see <https://www.ccr-zkr.org/12050200-en.html\#03> accessed 5 July 2018.

62 Appendix A - CIV UR: Uniform Rules concerning the Contract of International Carriage of Passengers by Rail

Appendix B - CIM UR: Uniform Rules concerning the Contract of International Carriage of Goods by Rail

Appendix C - RID: Regulation concerning the International Carriage of Dangerous Goods by Rail

Appendix D - CUV UR: Uniform Rules concerning Contracts of Use of Vehicles in International Rail Traffic

Appendix E - CUI UR: Uniform Rules concerning the Contracts of Use of Infrastructure in International Rail Traffic

Appendix F - APTU UR: Uniform Rules concerning the Validation of Technical Standards and Adoption of Uniform Technical Prescriptions applicable to Railway Material intended to be used in International Traffic

Appendix G - ATMF UR: Uniform Rules concerning the Technical Admission of Railway Material used in International Traffic. 


\section{Research handbook on maritime law and regulation}

Arbitration Tribunal described in Articles 29 to 32. Paragraph 2 of Article 28 also provides that: "Other disputes arising from the interpretation or application of the Convention and of other conventions elaborated by the Organisation, if not settled amicably or brought before the ordinary courts or tribunals may, by agreement between the parties concerned, be referred to an Arbitration Tribunal."

Following these rules, we can deduce that the mission of interpreting the COTIF and its appendices is entrusted to a special arbitration tribunal that must be seized when the dispute arises between State Parties to the OTIF, and which optionally may be seized when the dispute arises between parties to a contract for railway carriage. In theory, resorting to a specialized body is appropriate for improving uniform interpretation. Regrettably, the system does not contain a preliminary ruling procedure that would enable the courts of the State Parties to petition the organization directly, though I must admit that an arbitration tribunal may not be appropriate for this purpose (whereas a permanent body would be).

Moreover, as this body is not a permanent court but an arbitration tribunal the composition of which may change from one case to another, there is no guarantee of uniform interpretation. In fact, no one has as yet asked for such an arbitration tribunal to be constituted. The following explanation can be found on the OTIF website:

The reliability and clarity of the general rules prescribed in COTIF have so far meant that no arbitration has been necessary. To date, there has not been any dispute between Member States or any need to interpret COTIF that has required the arbitration procedure to be used. Using the uniform law of COTIF, the national courts have been able to find satisfactory solutions. ${ }^{63}$

Such statement appears to be rather optimistic, as it is doubtful that no interpretation discrepancies have been created by the decisions rendered by national courts. Inadequate knowledge of this system is a more credible explanation. And perhaps also, for those who may be aware of this mechanism, the cumbersomeness of the system.

In the end, this internal mechanism suffers from the same disadvantages as the ICJ system, as the procedure does not seem to be easily accessible to private operators.

Another way to fight interpretation discrepancies is to use terminology that is free from culture-bound connotations when drafting international conventions.

\section{B. Terminology}

To reduce differences related to legal culture, several studies and tests have been carried out on the terminology used to draft these conventions. Neutral terms ${ }^{64}$ and definitions contribute to uniform interpretation. ${ }^{65}$ In that regard, the work conducted for the

$63<$ http://otif.org/en/?page_id=61> accessed 3 January 2018.

64 See Michael Joachim Bonell and Roberta Pelegi, 'UNIDROIT Principles of International Commercial Contracts and Draft Common Frame of Reference: A Synoptical Table' [2009] Uniform Law Review 437.

65 Marie-Caroline Pitton, Le Rôle du Jugement étranger dans l'interprétation du droit conventionnel uniforme (Eleven International Publishing 2013). 
drafting of the UNIDROIT Principles was distinctive, as a working group on common terminology was in fact set up. ${ }^{66}$

But these methods cannot get rid of every interpretation issue. That is why there should be more interpretation guidance at the judges' disposal.

\section{Interpretation Guidance}

Being a matter of interpretation, the guidance given judges should be improved, both regarding the method of interpretation and the bodies competent to interpret. ${ }^{67}$

To improve interpretation guidance on an international level, the use of the Vienna Convention on Treaties should be promoted. Moreover, every new international convention should contain specific provisions on interpretation, such as Article 7 of the CISG. ${ }^{68}$ But we are all aware that this is just wishful thinking. Even one of the most recent conventions related to maritime carriage contracts, the Rotterdam Rules, does not contain any similar provision except Article 2, which refers to the need for international interpretation of the instrument. ${ }^{69}$

Another line of research concerns the creation (or the activation) of dedicated interpretation bodies for each convention. In this field it is necessary to distinguish between conventions that are linked to a "parent" international organization and others that are not, as legal grounds may or may not exist. A so-called "parent organization" is the international organization that initiates the procedure for drafting and adopting a specific convention.

There are two types of "parent" organizations. First, the organizations of general competence, which are entitled to launch a convention procedure on a wide range of topics included in their purpose. The Hague Conference, UNIDROIT, or the United Nations, which have universal competence, belong to this category. Second, organizations created for a special purpose, with a narrower field of competence. Such specialized organizations exist in the field of transport: the $\mathrm{ICAO}^{70}$ for air transport, the IMO and $\mathrm{CMI}^{71}$ for maritime transport, and the OTIF for railway transport. ${ }^{72}$

66 Aline Tenenbaum, 'Droit européen des contrats: mythe ou réalité? L'enjeu et les difficultés d'une terminologie commune' (2009) 61(1) Revue internationale de droit comparé 177 <www.persee.fr/doc/ridc_0035-3337_2009_num_61_1_19844> accessed 3 January 2018.

67 Cécile Legros, 'Interpreting Maritime Conventions and Shipping Contracts with European Soft Law Instruments' (2015) 1 European Journal of Commercial Contract Law 32. Also available in Common Core, PECL and DCFR: Could They Change Shipping and Transport Law? (Intersentia 2015).

68 John Felemegas, 'The United Nations Convention on Contracts for the International Sale of Goods: Article 7 and Uniform Interpretation' [2001] 115 Pace Int'l Law Review <http:// cisgw3.law.pace.edu/cisg/biblio/felemegas.html> accessed 3 January 2018.

69 See above p. 9.

70 See below p. 18.

71 See below p. 19.

72 See OTIF explanatory report <https://www.cit-rail.org/en/rail-transport-law/cotif/> accessed 6 July 2018. 
The purpose of this chapter is to focus on these special interpretation bodies, looking for legal grounds to create such bodies in the parent conventions, ${ }^{73}$ or for other remedies when such grounds do not exist.

\section{CREATION OF INTERPRETATION BODIES AS A SOLUTION TO INTERPRETATION DISCREPANCIES}

The main explanation for discrepancies in the interpretation of international conventions is that there is no common authoritative body competent to deliver a unique interpretation applicable by all the courts of the conventions' State Parties.

In the literature dedicated to uniform law, the idea of creating interpretative bodies is frequently addressed. To cite just one example, in 1987 Professor Joachim Bonell proposed creating

an Editorial Board for the CISG composed of representatives of States which have actually ratified the convention and whose purpose would be to gather judicial decisions and bibliographic material relating to the convention from its own country. The board would proceed to comparative analysis of the material collected and would report annually to the Board evidencing the gaps in the convention's provisions source of diverging interpretations. (Emphasis added)

Whether the Board should be entrusted or not with the task of rendering non-binding interpretations of the convention remained unanswered. It was also suggested to extend this proposal to other international organizations for the conventions elaborated under their auspices. ${ }^{74}$ This proposal was based upon the model of the Permanent Editorial Board established by the National Conference of Commissioners on Uniform State Laws for the American Uniform Commercial Code. It must be noted, however, that such a board was never created, but this proposal may have led to the creation of the CISG Advisory Council presented below. ${ }^{75}$

Professor Bonell's suggestion may have failed because of the lack of a legal basis in the CISG itself or in the statute of UNCITRAL, its parent international organization.

Generally, international conventions are drafted under the auspices of one or several international organizations. This is the case for most transport conventions. But it does not mean that an institutional link with these organizations remains after the convention is adopted. For example, the CMR was discussed on the initiative of UNIDROIT, the International Road Union and the United Nations Economic Commission for Europe (UNECE), but none of these organizations can now be considered "parents" of that convention.

73 Failing a dedicated body provided in the convention itself. See above p. 15.

74 Michael Joachim Bonell, 'A Proposal for the Establishment of a Permanent Editorial Board for the Vienna Sales Convention' in International Uniform Law in Practice, Acts and proceedings of the 3rd Congress of UNIDROIT on Private Law, Rome 7-10 September 1987, pp. 241-44, Reproduced with the permission of Oxford University Press, Inc. <www.cisg.law. pace.edu/cisg/biblio/bonell.pdf> accessed 4 March 2019. See also Murray (n 48).

75 On this Council, see below p. 21. 
Other conventions have been adopted simultaneously with the creation of an international organization or at the initiative of such organization according to its statute. In such cases an institutional instrument governing the organization exists. And sometimes these institutional instruments (often called "Statute" or "Constitution") include provisions related to interpretation.

That is why it seems necessary to distinguish between international transport conventions that are elaborated by a parent international organization from those that are not. When a parent organization exists, the statutes of the international organizations may contain hidden provisions likely to provide grounds for interpretative committees. But when a transport convention cannot be formally linked with an international organization, the grounds for creating an interpretative committee is even less formal.

\section{A. Hidden Statutory Interpretative Committees}

Actually, no specific provisions related to interpretation bodies can be found in the statutes of international transport organizations, or in those of more general organizations. ${ }^{76}$ However, some statutory provisions could be used as grounds for the creation of an interpretation committee. ${ }^{77}$

Among the different international organizations studied in this chapter, the system of the Hague Conference is worth developing, as the interpretative process could serve as a model for other organizations. Such a system could be transferred to the field of air and maritime transport.

\section{The Hague interpretation mechanism}

The Hague Conference on Private International Law is an international organization for cross-border cooperation in civil and commercial matters. The statutory mission of the Conference is to work for the progressive unification of private international law rules through the adoption of international conventions. ${ }^{78}$

The Hague Conference statute provides for special commissions on the practical operation of certain Hague conventions. ${ }^{79}$ Such commissions are held periodically. Prior to these meetings, the Permanent Bureau of the Conference sends questionnaires to the Member States and to international organizations concerned by the topic. The material issued from these questionnaires will determine the strategic issues to be considered by the commission. These commissions are composed of experts: States' representatives and international organizations' representatives. Generally these experts

\footnotetext{
76 Except the COTIF, see above p. 13.

77 On this subject, see Olivier Deshayes, L'amélioration de l'application et de l'interprétation uniformes des conventions internationales relatives au contrat de transport: l'exemple de la faute caractérisée (PhD Thesis, Rouen Normandie University June 2018) 377 (unpublished manuscript, on file with author).

$78<$ https://www.hcch.net/en/about> accessed 4 March 2019.

79 Art 8 of the Statute of The Hague Conference on Private International Law (entered into force 15 July 1955): " $\$ 1$ : The Sessions and, in the interval between Sessions, the Council may set up Special Commissions to prepare draft Conventions or to study all questions of private international law which come within the purpose of the Conference."
} 
belong to the authorities in charge of the practical application of the convention concerned.

According to Article 8 of the Statute of the Hague Conference, the mission of the Special Commissions set up by the Council is: "to prepare draft Conventions or to study all questions of private international law which come within the purpose of the Conference". As the definition of their mission is rather vague, it happens that some of them in fact play the role of an interpretative committee. For example, a Commission on the Service convention ${ }^{80}$ was set up in 2003 to examine the difficulties caused by the phrase "civil or commercial matters", which defines the convention's scope of application, and to determine whether or not the courts applied an autonomous interpretation of these terms.

This experience indicates that even if interpretation is not formally a mission of these commissions, they have actually rendered interpretative recommendations on certain conventions.

As for the effect of these recommendations, it must be recognized that they are not binding at first sight. Some Courts in Switzerland and Netherlands have, however, made references to these recommendations. ${ }^{81}$ There are academic discussions on the enforceability of recommendations issued by organs of international organizations when based upon a legal basis, such as the statute of the Hague Conference, for example. Some authors believe that even if it is soft law, these recommendations may bind these organizations' Member States. ${ }^{82}$ But this issue is still controversial.

At least, from the point of view of the functions of law and its role in society, these recommendations can be considered a tool for collective action, thus producing cooperative international law.

It is now time to explore the statutes of international transport organizations to see if they contain provisions that could constitute a legal basis for the organization to adopt interpretative recommendations. Such mechanisms, though based on a legal instrument, will be characterized as "hidden" because the instrument in question was not designed for such a purpose.

\section{Hidden interpretation mechanisms in transport conventions}

From this perspective, both air and maritime transport organizations offer interesting prospects.

2.1 Air transport: ICAO The ICAO is a United Nations specialized agency, established to manage the administration and governance of the Convention on International Civil Aviation. It is governed by the Chicago Convention of 7 December 1944.

80 Convention of 15 November 1965 on the Service Abroad of Judicial and Extrajudicial Documents in Civil or Commercial Matters (adopted 15 November 1965, entered into force 10 February 1969) <https://www.hcch.net/en/instruments/conventions/full-text/?cid=17> accessed 5 January 2018.

81 Cantonal Court of Fribourg, 10 February 1999, cited in Christophe Bernasconi and Laurence Thebault, Practical Handbook on the Operation of the Hague Service Convention (3rd edn, Wilson and Lafleur Ltd 2006) no 58 - Hoge Raad, 15 June 2000, id no 108.

82 On this discussion, see Deshayes, L'amélioration de l'application et de l'interprétation uniformes des conventions internationales relatives au contrat de transport (n 76). 
Article 37 of this Convention provides a legal basis for the ICAO to adopt uniform "standards [and] methods" that, once adopted by the ICAO Council, become appendices to the Convention, thus acquiring the same legal status as the provisions of the Convention.

The ICJ, competent on the grounds of Article 84 of the Chicago Convention, has not had an opportunity to rule on the legal nature of these appendices. The French State Council (Conseil d'Etat) has considered that such appendices contained recommendations for State Parties to the Convention, but that they were not directly applicable before French courts. ${ }^{83}$

Even if in theory this provision confers law-making power on the organization, in practice it leads to the adoption of uniform technical standards and is not likely to be used to issue interpretative recommendations.

In this regard, the role of the legal committee is more relevant. It is composed of legal experts designated as representatives of and by Member States, and is open to the participation of all Member States and certain international organizations invited by the Council. This committee is an advisory body, as it may give advice to the Council and present recommendations on air transport issues. ${ }^{84}$ As the subject matter of such recommendations is not limited, it would seem that this committee is entitled to issue interpretative recommendations.

2.2 Maritime transport: IMO and CMI In the field of maritime transport, two major organizations govern international conventions: the IMO and the Comite Maritime International (CMI).

The IMO is the United Nations specialized agency with responsibility for the safety and security of shipping and the prevention of marine pollution by ships. It was created by an international convention ${ }^{85}$ and has the legal nature of an international organization.

The CMI is a non-governmental not-for-profit international organization, the purpose of which is to contribute to the unification of maritime law in all its aspects. But the purpose of the CMI is more focused on "trade" conventions, mostly conventions governing maritime contracts. A statute called a "Constitution" also governs this organization. ${ }^{86}$

The analysis of both statutes shows that even if they do not include "hidden" interpretation bodies, some provisions could provide grounds for interpretative recommendations.

83 Conseil d'Etat [CE], 20 November 1981, [1981] Rec CE $428<$ https://www.legifrance. gouv.fr/affichJuriAdmin.do?idTexte=CETATEXT000007667042 $>$ accessed 4 March 2019; Administrative Court of Appeal of Paris [CAA Paris], 10 February no. 96 PA02799 <https:// www.legifrance.gouv.fr/affichJuriAdmin.do?idTexte=CETATEXT000007436273 $>$ accessed 4 March; Conseil d'Etat [CE], 7 October 1998, no 185657 <https://www.legifrance.gouv.fr/ affichJuriAdmin.do?idTexte=CETATEXT000007994439 $>$ accessed 4 March 2019.

84 Art 8 of the Constitution of the Legal Committee, Assembly, Resolution A7-5.

85 Convention on the International Maritime Organization (adopted Geneva, 6 March 1948, entered into force 17 March 1958) United Nations, Treaty Series, vol 289, p. 3, and vol 1520, p. 297.

$86<$ https://comitemaritime.org/governance/constitution> accessed 27 March 2019. 
THE IMO CONVENTION According to Article 1 of the IMO Convention, the purposes of the Organization are:

- to encourage governmental co-operation on regulation and practices relating to technical matters regarding international trade shipping (a);

- to promote the adoption of maritime standards related to safety, efficiency of navigation and prevention and control of marine pollution (a);

- to eliminate discriminatory action and unnecessary restrictions by Governments affecting shipping engaged in international trade (b);

- to deal with unfair restrictive practices by shipping (c); marine environment (d)

- to develop exchange of information among Governments on such matters (e).

In order to achieve these missions, the organization is entitled to: "make recommendations upon matters arising under Article 1 (a), (b) and (c) that may be remitted to it by Members, by any organ or specialized agency of the United Nations or by any other intergovernmental organization or upon matters referred to it under Article 1 (d)" (Article 2a; emphasis added).

Article 11 of the Convention provides for its organs, including the Assembly and the Council. Among its various functions, set out in Article 15, the Assembly is entitled to perform the functions of the Organization (i) and to recommend to Members for adoption regulations and guidelines concerning the matters related to the Convention. The Council receives the reports, proposals and recommendations of the other organs of the Organization and transmits them to the Assembly with comments and recommendations (Article 21b).

Following this system, it is possible to imagine that the Assembly could issue recommendations regarding uniform application of the IMO conventions in the State Parties on the basis of reports issued by the other organs of the Organization and transmitted by the Council. Indeed, the phrasing of the Assembly's missions is vague enough to allow the adoption of this type of interpretative recommendations.

THE CMI CONSTITUTION According to Article 18 (c) of the Constitution, the Executive council is entitled to initiate works within the purpose of the Comite Maritime International and to establish working Groups to undertake such works.

The reports issued by these working groups may be referred to the Assembly as provided by Article $7 \mathrm{f}$, possibly leading to the adoption of resolutions during an international conference (Article 20).

As the very purpose of the CMI is to contribute to the unification of maritime law, it seems rather obvious that issues related to uniform application of maritime law by State Parties fall within this scope. As a consequence, and even if interpretation as such is not mentioned among the functions of any organ of this Organization, here again the functions attributed to the Assembly and the Council allow both these organs to issue interpretative recommendations of conventions. It is possible that such guidance will not remain merely soft law, as resolutions that are binding on State Parties can be adopted.

As a temporary conclusion it can be noted that in these statutory conventions, the functions of several organs are described with such plasticity that these organs may be 
able to issue interpretative recommendations that are likely to be followed by domestic courts applying the international conventions concerned.

But some transport conventions have no direct link with an international organization, which means other solutions must be found.

\section{B. Solutions When There is No Parent Organization}

If there is no parent organization, two solutions can be proposed. First, the creation of purely private interpretation bodies. Second, resorting to the UNCITRAL, whose mission includes any solution likely to improve uniform trade law.

\section{Private initiatives: the CISG advisory council ${ }^{87}$}

Facing the lack of adequate remedies to tackle discrepancies in the interpretation of the Convention on international sales of goods, ${ }^{88}$ a group of academics put forth an initiative for an advisory council.

Despite the existence of a very wide system of databases coordinated by UNCITRAL providing domestic case law on the Convention (CLOUT), which should enhance the dissemination of case law related to the CISG, diverging interpretation of this Convention persists. That is why a group of scholars set up the advisory council (AC), which aims to: "promot[e] a uniform interpretation of the CISG". ${ }^{89}$

The mechanism relies on a panel of famous scholars who are specialized in international sales' law and deliver authoritative opinions on topics concerning the uniform application and interpretation of the CISG. ${ }^{90}$ The topics are chosen on the request of a third party or at the council's initiative, which is mostly the case so far. But international organizations, professional associations and adjudication bodies may also submit requests. The council's opinions have only persuasive value, ${ }^{91}$ but the authority of the experts comprising the panel is sufficient to ensure the opinions' credibility.

However, it must be noted that the success of this enterprise remains limited. The opinions of the CISG-AC have been quoted in only a few courts' decisions and seem to have been used only as additional support for the decision rather than as a legal ground..$^{92}$

87 Ingeborg Schwenzer, 'The CISG Advisory Council' [2012] 2 Nederlands Tijdschrift voor Handelrecht 51; Joshua D Karton and Lorraine de Germiny, 'Has the CISG Advisory Council Come of Age ?' [2009] 27 Berkeley J. Int'l Law $448<$ http://scholarship.law.berkeley.edu/bjil/ vol27/iss2/4> accessed 3 January 2018.

88 United Nations Convention on Contracts for the International Sale of Goods (Vienna, 1980) (CISG) (adopted 11 April 1980, entered into force 1 January 1988).

89 See website <www.cisgac.com/about-us/> accessed 4 March 2019.

$90<$ www.cisgac.com/opinions/> accessed 4 March 2019.

91 Franco Ferrari, 'Interprétation uniforme de la Convention de Vienne de 1980 sur la vente internationale' [1996] 48(4) Revue Internationale de droit comparé 813 <www.persee.fr/web/ revues/home/prescript/article/ridc_0035-3337_1996_num_48_4_5312> accessed 3 January 2018.

92 Germany (quoting CISG-AC Opinion No. 13): BGH, [2014] CISG online No 2513; Netherlands (quoting CISG-AC Opinion No. 2): Gerechtshof Arnhem, [2010] LJN BL7399, CISG online No. 2095; United States (quoting CISG-AC Opinion No 3): Tee Vee Toons, Inc 


\section{Research handbook on maritime law and regulation}

Several events were organized for the 60th anniversary of the CMR. ${ }^{93}$ The first colloquium was held in France on the actual anniversary date, on the subject of identifying the discrepancies in the application of the convention by the domestic courts of the State Parties. A few remedies were also explored. ${ }^{94}$ During a second conference held in Rotterdam, ${ }^{95}$ I presented a paper on setting up a council for CMR issues that would be similar to the CISG Advisory Council. ${ }^{96}$ I will not go into detail here, but will touch on that paper's main points.

The CISG-AC system is much more flexible than resorting to international courts, arbitration tribunals or even statutory committees. In addition, it appears to be transferable to several conventions, especially to the CMR. Even if domestic courts currently use the CISG-AC and disseminate its opinions in only very limited fashion, the fact remains that this Council can nevertheless serve as a model for transport conventions such as the CMR, for which there is no statutory body that can deliver interpretative recommendations. ${ }^{97}$ There is in fact no equivalent to the ICAO or the IMO/CMI in the field of carriage by road. ${ }^{98}$

Provided such opinions are effectively disseminated among the courts of State Parties to a convention, I strongly believe that, in the long term, these opinions or recommendations could influence domestic case law. But the unofficial character of such an initiative still constitutes its weak point.

Apart from the creation of an effective international interpretative body, the initiative of issuing interpretative recommendations could come from the UN, and more specifically from UNCITRAL.

\section{The United Nations, a supplementary "parent" organization}

In cases where there is no specialized organization, there is one organization that could play this role of "parent organization" for all conventions related to transport: the United Nations, and, more specifically, the UNCITRAL.

(d/b/aTVTRecords) \& Steve Gottlieb, Inc (d/b/aBiobox) v Gerhard Schubert GmbH [2006] WL2463537 (.DNY 2006), CISG online No. 1272.

93 60th Anniversary of the CMR Convention (Convention on the Contract for the International Carriage of Goods by Road, 19 May 1956) - Comparative issues in the application of the Convention by Contracting Parties: What differences?, Symposium Rouen (France), 19-20 May 2016. Proceedings published in (2016) 21 Uniform Law Review. About this conference, see <https://academic.oup.com/ulr/issue/21/4> accessed 27 March 2019; proceedings published in the Uniform Law Review, ${ }^{\circ} 4 / 2016$.

94 Legros (n 27) 426.

95 International Conference 60 years CMR: Future proof or time for a reform?, Erasmus University, Rotterdam, 5-6 October 2016. Proceedings: publication in progress.

96 C Legros, 'The CISG Advisory Council: A Model to Improve Uniform Application of the CMR?' (2017) 1 European Journal of Commercial Contract Law $1877<$ doi 10.7590/187714617 X14913986024443> accessed 3 January 2018.

97 The same conclusion can be reached for the Budapest Convention on the Contract for the Carriage of Goods by Inland Waterway (CMNI) (adopted 3 October 2000, entered into force 1 April 2005). OJ L 276/3.

98 The International Road Union (IRU) is a professional association, not a governmental body. 
As announced on its website, this Commission constitutes "the core legal body of the United Nations system in the field of international trade law".99 Such body, with universal membership, is specialized in commercial law reform as well as the modernization and harmonization of rules on international business. As the purpose of this commission is clearly focused on harmonization, the issues related to the application of uniform law certainly fall within its sphere of competence.

However, as it is not an international organization itself, there are not institutional provisions. Its 1966 "birth certificate" 100 specifically states that one of its purposes is to "promote harmonization and unification of international trade law" and that "it should promote ways and means of ensuring a uniform interpretation and application of international conventions and uniform law in the field of international trade". ${ }^{101}$ Moreover, its mandate also provides that UNICTRAL has the mission of "collecting and disseminating information on national legislation and modern legal developments, including case law, in the field of the law of international trade". ${ }^{102}$

This commission accomplishes its mission through specialized working groups in charge of the preparatory work on topics listed on UNCITRAL's work programme. Working Group III comprised a session on international transport held between 2002 and 2008 whose major achievement was the Rotterdam Rules (UN Convention on contracts for the international carriage of goods wholly or partly by sea). ${ }^{103}$

Despite its major mission in favour of harmonization, UNCITRAL has no legal power or legal body tasked with achieving uniform interpretation of conventions adopted under its auspices. As a specialized commission of the United Nations, the only bodies that can be used are the UN organs themselves. As I indicated earlier, however, even if some provisions might seem relevant, in practice resorting to the ICJ to solve interpretation discrepancies proves rather inefficient. ${ }^{104}$

Other UN commissions, such as the regional commissions, could also be involved in such a process. The UNECE is a good example. Set up in 1947 by the Economic and Social Council (ECOSOC), this commission is one of the main UN bodies. UNECE's major aim is to promote pan-European economic integration. The commission includes 56 Member States in Europe, North America and Asia and involves over 70 international professional organizations and other non-governmental organizations. The UNECE's statute, called "terms of reference", was elaborated by the ECOSOC. 105

This commission's purposes include (Article 1(1)):

(b) Make or sponsor such investigations and studies of economic and technological problems of and developments within member countries of the Commission and within Europe generally as the Commission deems appropriate;

\footnotetext{
99 <www.uncitral.org/uncitral/en/about_us.html> accessed 4 March 2019.

100 Resolution by the General Assembly of 17 December 1966 (Resolution 2205(XXI)).

101 Mandate: para f. Quoted in A Guide to UNCITRAL, Basic Facts about the United Nations Commission on International Trade Law (United Nations 2013) 1 <www.uncitral.org/pdf/ english/texts/general/12-57491-Guide-to-UNCITRAL-e.pdf> accessed 4 March 2019.

102 Mandate: para d.

103 See above p. 22.

104 See above p. 7.

105 E/ECE/778/Rev.5.
} 


\section{Research handbook on maritime law and regulation}

(c) Undertake or sponsor the collection, evaluation and dissemination of such economic, technological and statistical information as the Commission deems appropriate.

In addition, Article 1(4) of the terms of reference provides that:

The Commission is empowered to make recommendations on any matter within its competence directly to its member Governments, Governments admitted in a consultative capacity under paragraph 8 below, and the specialized agencies concerned. The Commission shall submit for the Council's prior consideration any of its proposals for activities that would have important effects on the economy of the world as a whole. (Emphasis added)

On the basis of such provisions, it would be possible for the UNECE to issue interpretative recommendations for Member States and specialized agencies. Effectiveness of these recommendations to Member States could be ensured, provided these States develop an adequate system of information and publicity for their courts. On the contrary, however, recommendations addressed to specialized agencies encounter the same limits already discussed. ${ }^{106}$ Relying on this regional commission could be useful to a certain extent for regional conventions such as the CMR or the COTIF-CIM, ${ }^{107}$ as both conventions were adopted with the involvement of UNECE.

\section{CONCLUSION}

The purpose of this chapter was to discuss whether solutions can be found to create specialized interpretation bodies competent to issue uniform interpretative recommendations for domestic courts to use when applying international transport conventions.

I have shown that whether such conventions are linked to a parent organization or not, several legal tools exist to enable the adoption of interpretative recommendations. From a legal point of view, such recommendations may not be binding on State Parties to these conventions or on their domestic courts. However, a considerable advantage for the improvement of uniform interpretation could be gained from disseminating and publicizing them.

Improving uniform application and interpretation of international transport conventions supposes first that the decisions issued by national courts are properly collected on a common basis and indexed by official national organizations that can ensure proper dissemination of such decisions. And second, it requires the creation of interpretative committees within specific international organizations or a general committee under the auspices of the UNCITRAL or other UN bodies.

The tools exist. What is needed is the political impetus to encourage such a movement within international organizations or to fund academic initiatives such as the CISG-AC.

My personal preference is for the private academic initiative, even though I must admit that its lack of a legal basis is a serious weakness. However, such councils have

106 See above.

107 Even though the COTIF-CIM has a "parent organization", that is, the OTIF, which contains relevant provisions regarding uniform interpretation. See above p. 13. 
the advantage of intellectual independence from States and businesses, which enables them to deliver opinions free from political or economic influences. Of course, the question of how to determine the appropriate composition of the panel of experts remains unsolved. But the success of such initiatives relies on the neutrality and degree of expertise of the panel, which must be sufficient to guarantee professionalism. But above all, setting up such councils would be much easier than trying to go through the cumbersome process required to obtain a result from an international organization. 